\title{
SYNTAXONOMIC AND NOMENCLATURAL NOTES ON THE SCREE VEGETATION OF CAUCASUS
}

\author{
Elena A. BELONOVSKAYA ${ }^{1}$, \\ Ladislav MUCINA $^{2 *} \&$ Jean-Paul THEURILLAT ${ }^{3}$
}

\begin{abstract}
We present description of a new class for the high-altitude screes of the Caucasus (the Lamio tomentosi-Chaerophylletea humilis) and two alliances such as the Scrophulario minimae-Symphyolomion graveolentis (Chaerophylletalia humilis, Lamio tomentosi-Chaerophylletea humilis) and the Scrophulario variegatae-Epilobion dodonaei (Epilobietalia fleischeri, Thlaspietea rotundifolii).

Key words: Georgia, alpine vegetation, Russian federation, riverine terraces, syntaxonomy.

Izvleček

V članku predstavljamo opis novega razreda na visoko ležečih meliščih na Kavkazu (Lamio tomentosi-Lamietea tomentosi) in dveh zvez - Scrophulario minimae-Symphyolomion graveolentis (Chaerophylletalia humilis, Lamio tomentosi-Chaerophylletea humilis) in Scrophulario variegatae-Epilobion dodonaei (Epilobietalia fleischeri, Thlaspietea rotundifolii).

Ključne besede: Gruzija, alpinska vegetacia, Ruska federacija, rečne terase, sintaksonomija.
\end{abstract}

\section{INTRODUCTION}

The communities of the Thlaspietea rotundifolii (Braun-Blanquet 1948, Zollitsch 1966, Englisch et al. 1993, Valachovič et al. 1997 etc.) are a common appearance in scree habitats of temperate, boreal and subarctic zones of Europe, where they could be found in all vegetation altitudinal belts, from the planare and colline belts as high as the alpine and subnival belts. In the mediterranean-climate regions of the Iberian Peninsula they are replaced by the Phagnalo-Rumicetea indurati (Rivas Goday et Esteve 1972) Rivas-Martínez, Izco et Costa 1973 (e.g. Ortiz \& Puglar 2000, Rivas-Martínez et al. 2011) and in the (sub)mediterranean regions of the Central and Eastern Mediterranean, they give way to the Drypidetea spinosi which, in our syntaxonomic concept, also includes the Scrophulario-Helichrysetea italici S. Brullo et al. 1998 (Brullo et al. 1998) and the Onosmo polyphyllaePtilostemonetea Korzhenevsky 1990 (see Golub et al. 2011 for the latest syntaxonomic synthesis).

In Caucasus, Onipchenko (2002a: Table 3.1) described the Chaerophylletalia humilis and placed this order within the Thlaspietea rotundifolii, although on page 18 he also noted that practically all diagnostic species of the class are missing in the Caucasian communities. Onipchenko (l.c.) also suggested that there were some diagnostic species of the European alliances and orders and therefore he decided to classify his new order (Chaerophylletalia humilis) within the Thlaspietea

\footnotetext{
${ }^{1}$ Institute of Geography, Russian Academy of Sciences, Staromonetny 2, 109017 Moskva, Russian Federation; E-mail: belena53@mail.ru

${ }^{2}$ Iluka Chair in Vegetation Science \& Biogeography, School of Plant Biology, The University of Western Australia, 35 Stirling Highway, Crawley WA 6009, Australia; E-mail: Laco.Mucina@uwa.edu.au

${ }^{3}$ Centre alpien de Phytogéographie, Fondation J.-M. Aubert, Case postale 71, CH-1938 Champex-Lac, Switzerland; Laboratoire de Biogéographie, Section de Biologie, Université de Genève, 1, ch. de l'Impératrice, Case postale 60, CH-1292 Chambésy, Switzerland; E-mail: jean-paul.theurillat@unige.ch

* corresponding author
} 
rotundifolii. In fact only Oxyria digyna, Cryptogramma crispa and Epilobium dodonaei would qualify at the latter group. Interestingly, these species occur in the Caucasian scree communities at lower altitudes (perhaps (sub)montane to subalpine zone). The high altitudes (alpine to subnivale zones) of the Caucasus range are home to endemic-rich scree communities that appear to be floristically very different from the Thlaspietea rotundifolii of Europe (see also Nakhutsrishvili \& Gagnidze 1999; Nakhutsrishvili 2003).

Belonovskaya (2012; based on earlier paper by Belonovskaya \& Korotkov 2002) developed the Onipchenko's (2002) remark on the poor floristic relationship of the Caucasus scree communities and those of Europe further and introduced a new syntaxonomic concept - the Veronico telephiifoliae-Lamietea tomentosi, including one new order (Veronico telephiifoliae-Lamietalia tomentosi), with two new alliances (Drabo scabrae-Eunomion rotundifoliae, Scrophulario minimae-Symphyolomion graveolentis). Belonovskaya's (2012) paper however have not engaged fully with the syntaxonomy proposed by Onipchenko (2002) and all the suggested new syntaxonomic units (class, order and the alliances) are rendered either invalid according to the International Code Phytosociological Nomenclature; Weber et al. 2000) or (in one case) should be considered synonymous with an earlier syntaxonomic concept of Onipchenko (2002).

The prime aim of this paper is to validate the syntaxon names (or introduce a new one) and contribute to clarification of the syntaxonomic relationship of the Onipchenkos's syntaxa and those suggested by Belonovskaya (l.c.) in the light of the new syntaxonomic-nomenclatural synthesis undertaken within so called 'EuroVegChecklist' (Mucina et al. in prep.).

\section{NOMENGLATURE OF THE NAME 'VERONICO TELEPHIIFOLIAE- LAMIETEA TOMENTOSI'}

We agree that the endemic-rich, high-altitude scree communities of the Caucasus should be considered as a syntaxonomic concept different from the Thlaspietea rotundifolii. However, name 'Veronico telephiifoliae-Lamietea tomentosi' (coined to accommodate these high-altitude Caucasian scree communities) has been invalidly (Art. 2b of the ICPN) published in Belonovskaya (2012:
967) because the name of the unique order - the 'Veronico telephiifoliae-Lamietalia tomentosi' - include in the original diagnosis of the new class, was invalidly published at the time of the publication of the class name.

Indeed, the original diagnosis of the Veronico telephiifoliae-Lamietalia tomentosi contains two new alliances: the Drabo scabrae-Eunomion rotundifoliae and Scrophulario minimae-Symphyolomion graveolentis. There are four new associations in the original diagnosis of the Drabo scabrae-Eunomion rotundifoliae and three new associations in the Scrophulario minimae-Symphyolomion graveolentis (Belonovskaya 2012). All these seven associations are validly published because their original diagnosis contains only the type relevé (in Russian) presented in the Table 1 in Belonovskaya (2012) and each type relevé containing the name-giving taxa of respective association. On the other hand, both names of the new alliances are invalidly published because their type, indicated in the bottom of the Table 1 is given in Russian not matching the demand of the Art. 5 of the IPCN (Weber et al. 2000) that requires (expressis verbis) using the Latin terms typus or holotypus. Because of this technicality, the original diagnosis of the "Veronico telephiifoliae-Lamietalia tomentosi' containing no validly published alliances, the name remains invalidly published (Arts. 2b and 8 of the IPCN).

Besides, even if the new alliance Drabo scabraeEunomion rotundifoliae (Belonovskaya 2012) was validly published, the latter alliance name would have become automatically a superfluous name for the validly published Chaerophyllion humilis Onipchenko 2002 which was listed by Belonovskaya (2012) in the synonymy of the Drabo scabraeEunomion rotundifoliae on p. 968. Similarly, if the new order Veronico telephiifoliae-Lamietalia tomentosi were validly published, it would have been a homotypical synonym for the validly published Chaerophylletalia humilis Onipchenko 2002. It appears that syntaxonomically this order matches the Belonovskaya's 'Veronico telephiifoliae-Lamietalia tomentosi'. Onipchenko (2002a: 168) listed both name-giving taxa (Lamium tomentosum and Veronica telephiifolia; syn. V. minuta C.A. Meyer; see Fig. 1) in the diagnosis of Chaerophylletalia humilis.

In order to avoid confusion in future, we introduce a new name for the invalid syntaxonomic concept of the 'Veronico telephiifoliae-Lamietea tomentosi' and by recognising the role of Chae- 


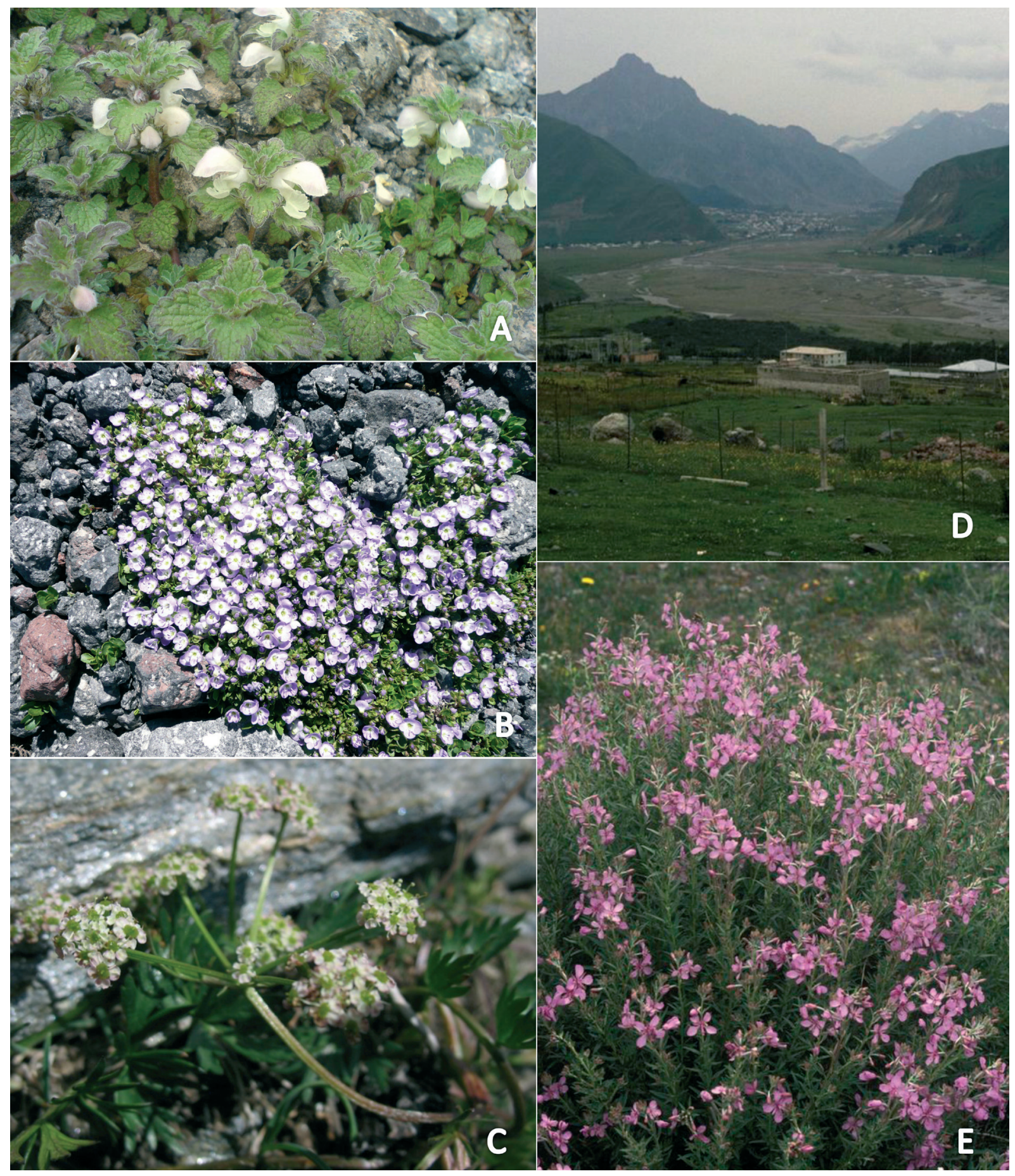

Figure 1: Selected character species of the Lamio tomentosi-Chaerophylletea humilis: A: Lamium tomentosum, B: Veronica minuta, C: Chaerophyllum humile. Broad valley of the Tergi (Terek) River near the town of Stepantsminda in Caucasus, Republic of Georgia with extensive terraces supporting communities of the Murbeckiello huetii-Epilobion dodonaei (D); Epilobium dodonaei photographed on the alluvial terraces of the Tergi (Terek) River, Georgia. Photo credits: A-C photos is Mikhail Dokukin (Nalchik, Kabardino-Balkaria, Russia), D-E: L. Mucina.

Slika 1: Izbrane značilnice razreda Lamio tomentosi-Chaerophylletea humilis: A: Lamium tomentosum, B: Veronica minuta, C: Chaerophyllum humile. Široka dolina reke Tergi (Terek) River v bližini mesta Stepantsminda na Kavkazu, Gruzija z ekstenzivnimi terasami, kjer se pojavljajo združbe zveze Murbeckiello huetii-Epilobion dodonaei (D); Epilobium dodonaei je fotografiran na aluvialni terasi reke Tergi (Terek), Gruzija. Foto: A-C Mikhail Dokukin (Nalchik, Kabardino-Balkaria, Russia), D-E: L. Mucina. 
rophyllum humilis as one of the local dominating species, we coin the name and concept of the $L a$ mio tomentosi-Chaerophylletea humilis (for the full protologue see below).

\section{THE CASE OF MURBECKIELLION HUETII ONIPCHENKO 2002}

The concept and name Murbeckiellion huetii was introduced for the first time by Onipchenko (2002a) who classified two associations within this alliance - the Hyalopoo ponticae-Oxyrietum digynae Onipchenko 2002 from siliceous, snowrich alpine moraine habitats and the Scrophulario variegatae-Epilobietum dodonaei which was designated as the typus of the alliance. The latter association, however, was not validly described because the typus of the association has not been assigned. The designation of the typus of the Scrophulario variegatae-Epilobietum dodonaei was attempted by Onipchenko (2002b) who selected (relevé) '26/95, Table 3.3' in Onipchenko (2002a) as the typus. This attempt was, however, invalid since there are two relevés designated as 26/95: 0 26/95 and 1 26/95 in Table 3.3. Because the choice of the typus was not unequivocal, this validation cannot be recognised, hence both the Scrophulario variegatae-Epilobietum dodonaei and the Murbeckiellion huetii remain invalidly described.

The Murbeckiellion huetii is a syntaxonomically heterogeneous concept. The Hyalopoo ponticae-Oxyrietum digynae Onipchenko 2002 is floristically (and ecologically) closer to the Hyalopoion ponticae Rabotnova et Onipchenko in Onipchenko 2002 than any syntaxonomic unit of the Lamio tomentosi-Chaerophylletea humilis. The Scrophulario variegatae-Epilobietum dodonaei, on the other hand should be classified with the Epilobietalia fleischeri; it is characteristic of gravel alluvial banks of mountain streams and Epilobium dodonei plays a major role in these community (see Fig. 1A-E). It is therefore not our intention to validate the Murbeckiellion huetii, but rather coin a new name that would better represent the vegetation of gravel terraces of Caucasus - the Murbeckiello huetii-Epilobion dodonaei (for the protologue see below).

The low-altitude Murbeckiello huetii-Epilobion dodonaei is classified here into the Epilobietalia fleischeri Moor 1958 nom. cons. propos. (Raus et al. in prep.) of the Thlaspietea rotundifolii.

\section{DESCRIPTION OF THE NEW SYNTAXA AND THE NEW SYNTAXONOMIC SCHEME FOR THE CAUCASIAN SCREE VEGETATION}

\begin{abstract}
Lamio tomentosi-Chaerophylletea humilis Belonovskaya, Mucina et Theurillat classis nova hoc loco Holotypus: Chaerophylletalia humilis Onipchenko 2002 (Onipchenko 2002a: 18, 21)
\end{abstract}

Synonym: Veronico telephiifoliae-Lamietea tomentosi Belonovskaya 2012 (Arts. 2b \& 8 of the ICPN) Diagnostic taxa: Cerastium multiflorum, Corydalis alpestris, Jacobaea erucifolia subsp. arenaria, furinea humilis, Lamium tomentosum, Veronica telephiifolia

Chaerophylletalia humilis Onipchenko 2002 Synonym: Veronico telephiifoliae-Lamietalia tomentosi Belonovskaya 2012 (Arts. 2b \& 8 of the ICPN)

Chaerophyllion humilis Onipchenko 2002 Synonym: Drabo scabrae-Eunomion rotundifoliae Belonovskaya 2012 (Arts. 5 \& 8 of the ICPN)

Diagnostic taxa: Cerastium alpinum, Chaerophyllum humile, Delphinium caucasicum, Draba scabra, Eunomia rotundifolia, Potentilla gelida, Saxifraga moschata, Tephroseris integrifolia, Veronica minuta

Veronico minutae-Chaerophylletum humilis Onipchenko 2002

Cruciato tauricae-Chaerophylletum humilis Belonovskaya 2012

Saxifrago sibirica-Alopecuretum sericei Belonovskaya 2012

Myosotido alpestris-Potentilletum gelidae Belonovskaya 2012

Scrophulario minimae-Symphyolomion graveolentis Belonovskaya, Mucina et Theurillat all. nova hoc loco

Holotypus: Cruciato tauricae-Pseudovesicarietum digitatae Belonovskaya 2012 Diagnostic taxa: Cruciata taurica, Scrophularia minima, Symphyoloma graveolens

Cruciato tauricae-Pseudovesicarietum digitatae Belonovskaya 2012

Ranunculetum arachnoidei Belonovskaya 2012

Anthemidetum creticae Belonovskaya 2012 Cerastietum alpini Belonovskaya 2012 
Thlaspietea rotundifolii Br.-Bl. 1948

Epilobietalia fleischeri Moor 1958 nom. cons. propos.

\begin{abstract}
Murbeckiello huetii-Epilobion dodonaei Belonovskaya, Mucina et Theurillat all. nova hoc loco

Holotypus: Scrophulario variegatae-Epilobietum dodonaei Onipchenko ex Belonovskaya, Mucina et Theurillat ass. nova hoc loco; Holotypus: Onipchenko 2002a: Table 3.3, relevé 11094

Synonym: Murbeckiellion huetii Onipchenko 2002 nom. inval. (Arts. 5 \& 8 of the ICPN)

Diagnostic species: Epilobium dodonaei, Murbeckiella huetii
\end{abstract}

\section{ACKNOWLEDGEMENTS}

We thank Thomas Raus (Berlin, Germany) for checking the nomenclature and taxonomy of the diagnostic species mentioned in our paper. Marie Lochman (Perth, Australia) kindly scanned slides and Mikhail Dokukin (Nalchik, Russia) for the photos used in Figure 1. Zaza Kikvidze identified the locality in the Tergi River valley. LM thanks Gia Nakhutrishvili (Tbilisi, Georgia) and Georg Grabherr (Vienna, Austria) for making the visit to Caucasus in 1990 possible.

\section{REFERENCES}

Belonovskaya, E. A. 2012: Klassifikatsiya rastile'nykh gruppirovok na osypyakh v alpiiskom noyase Severnogo Kavkaza. (Classification of plant communities on screes in the alpine belt of the Northern Caucasus.) Izvestiya Samarskogo Nauchnogo Tsentra Rossiiskoi Akademii Nauk 14: 967-970. (in Russian)

Belonovskaya, E.A. \& Korotkov, K.O. 2002: Raznoobrazi'e rastitel'nosti alpiiskogo poyasa Bol'shogo Kavkaza. (Alpine vegetation diversity on the Greater Caucasus.) Izvestiya Rossiiskoi Akademii Nauk, Seria geograficheskaya. N2: 89-96. (in Russian)

Braun-Blanquet, J. 1948: La végétation alpine des Pyrénées orientales. Consejo Superior de Investigaciones Científicas, Barcelona, ES.
Brullo, S., Scelsi, F. \& Spampinato, G. 1998: Considerazioni sintassonomiche sulla vegetazione perenne pioniera dei substrati incoerenti dell'Italia meridionale e Sicilia. Itinera Geobotanica 11: 403-424.

Englisch, T., Valachovič, M., Mucina, L., Grabherr, G. \& Ellmauer, T. 1993: Thlaspietea rotundifolii. In: Grabherr, G. \& Mucina, L. (eds.) Die Pflanzengesellschaften Österreichs. Teil I, pp. 276-342. G. Fischer Verlag, Jena,

Golub, V.B., Greshushkina, N.A., Sorokin, A.N. \& Nikolaichuk, L.F. 2011: Rastitel'nye soobshchestva klassa Onosmo polyphyllae-Ptilosmetea Korzhenevsky 1990 na territorii Chernomorskogo poberezhya Kavkaza i Krymskogo poluostrova. (Vegetation of the class of Onosmo polyphyllae-Ptilosmetea Korzhenevsky 1990 on territory of Black Sea coast of Caucausus and of the Crimean Peninsula.) Rastitel'nost' Rossii 17-18: 3-16. (in Russian)

Nakhutsrishvili, G. 2003: High mountain vegetation of the Caucasus region. In: Nagy, L., Grabherr, G., C. Körner \& Thompson, D.B.A. (eds.) Alpine biodiversity in Europe. pp. 93103. Springer, Heidelberg.

Nakhutsrishvili, G. \& Gagnidze, R. 1999: Die subnivale und nivale Hochgebirgsvegetation des Kaukasus. Phytocoenosis 11: 173-183.

Onipchenko, V. G. 2002a: Alpine vegetation of the Teberda Reserve, the Northwestern Caucasus. Veröffentlichungen des Geobotanischen Institutes ETH Stiftung Rübel Zürich 130: 1-168.

Onipchenko, V. G. 2002b: Tipifikatsiya nekotorykh assotsiatsii skalno-osypnoi rastitel'nosti Severo-Zapadnogo Kavkaza. (Typification of some associations of rock and scree vegetation of North-Western Caucasus.) Biulletin Moskovskogo Obshchestva Ispytatelei Prirody, Otdel Biologicheskii 107: 88-89. (in Russian)

Ortiz, S. \& Pulgar, I. 2000: As comunidades eurosiberianas da Clase Phagnalio-Rumicetea indurati en Galicia e Norte de Portugal (NO da Península Iberica). Nova Acta Cientifica Compostelana 10: 35-41.

Rivas-Martínez, S. et coautores 2011: Mapa de series, geoseries y geopermaseries de vegetación de España. (Memoria del mapa de vegetación potencial de España). Parte II). Itinera Geobotanica N.S. 18: 5-424.

Valachovič, M., Dierssen, K., Dimopoulos, P., Hadač, E., Loidi, J., Mucina, L., Rossi, G., Valle Tendero, F. \& Tomaselli, M. 1997: The 
vegetation on screes-a synopsis of higher syntaxa in Europe. Folia Geobotanica et Phytotaxonomica 32: 173-192.

Weber, H.E., Moravec, J. \& Theurillat, J.-P. 2000: International Code of Phytosociological Nomenclature. 3rd edition. Journal of Vegetation Science 11: 739-768.

Zollitsch, B. 1966: Soziologische und Ökologische Untersuchungen auf Kalkschiefern in hochalpinen Gebieten. Teil 1: Die Steinschuttgesellschaften der Alpen unter besonderer Berücksichtigung der Gesellschaften auf Kalkschiefern in den mittleren und östlichen Zentralalpen. Berichte der Bayerischen Botanischen Gesellschaft 40: 1-38.

Received 2.12.2013

Revison received: 6.2.2014

Accepted 6.2.2014 